\title{
Sensory profile and check-all-that-apply (cata) as tools for evaluating and characterizing syrah wines aged with oak chips
}

\author{
Natália Manzatti Machado Alencar ${ }^{\mathrm{a}, *}$, Tatiane Godoy Ribeiro ${ }^{\mathrm{a}}$, Bruna Barone ${ }^{\mathrm{a}}$, \\ Ana Paula André Barros ${ }^{\mathrm{b}}$, Aline Telles Biasoto Marques ${ }^{\mathrm{c}}$, Jorge Herman Behrens ${ }^{\mathrm{a}}$ \\ ${ }^{a}$ Department of Food and Nutrition, University of Campinas, Campinas, São Paulo 13083-862, Brazil \\ ${ }^{\mathrm{b}}$ Instituto Federal de Educação, Ciência e Tecnologia do Sertão Pernambucano, Petrolina, Pernambuco 56300-000, Brazil \\ ${ }^{\mathrm{c}}$ Brazilian Agricultura Research Corporation, Embrapa Tropical Semi-arid, Petrolina, Pernambuco 56302-970, Brazil
}

\section{A R T I C L E I N F O}

\section{Keywords:}

Syrah

Oak chip

Descriptive analysis

Sensory profile

CATA

\begin{abstract}
A B S T R A C T
Aging wine in oak barrels provides more complexity to the beverage, but due to the high cost of wood barrels, alternative aging methodologies such as the use of oak chips gain interest of winemakers in the new world of wines, particularly in the tropical regions. This paper reports the sensory profile and consumer perception of Syrah wine produced in the São Francisco Valley, Brazil, with the addition of American and French oak chips at different stages of the fermentation process. Higher intensity of color, coffee, woody, and sweet/caramelized aromas, sweet and woody taste were observed in the age wines as compared to a control wine (no chip addition). An affective sensory test $(N=129)$ revealed two segments of consumers exhibiting different attitudes to the wines: one group $(N=60)$ rejected all samples, whereas the other $(N=69)$ liked them moderately. In short, the findings provide relevant information for stakeholders in the new world of wine where oak barrels impact negatively on the cost of production of wines, as is the case in Brazil.
\end{abstract}

\section{Introduction}

Wine represents a category of products capable of activating a variety of meanings and representations. According to Amine and Lacœuilhe (2007); Parr, Mouret, Blackmore, Pelquest-Hunt, and Urdapilleta (2011), wines are one of the most described beverages in the literature (Brochet \& Dubourdieu, 2001). Directly related to the western culture (Mouret, Lo Monaco, Urdapilleta, \& Parr, 2013) numerous countries make and sell wines being part of the so-called "old world of wine" - Europe - in comparison with the more recent producers or the "new world of wine" - Americas, South Africa and Oceania (Le Parisien, 2016).

Brazil is part of the new world of wine and has been making efforts not only to improve the quality and the internal consumption of Brazilian wines, but also to promote the product into the global market (Vieira, Watanabe, \& Bruch, 2012). In this sense, the producers seek to consolidate regional identities, for example Vale dos Vinhedos and Campanha Gaúcha in southern Brazil, and invest in emerging locations such as the São Francisco Valley, in the states of Bahia and Pernambuco in the northeast part of the country (Niederle \& Vitrolles, 2010). This is a semi-arid region characterized by high temperatures, high insolation rates, absence of winter and water supplied in abundance from the São
Francisco River (Pereira, 2013).

Syrah, is among the cultivars of Vitis vinifera, the varietal that better adapted to the edafoclimatic conditions of the region (Camargo, de Amorim, Guerra, \& Lima, 2004), accounting for about 30\% of the vineyards. Syrah of the São Francisco Valley produces wine with intense red color and fruity (plum, raspberry and gooseberry), violet and pepper aromatic notes. Syrah wines from the São Francisco Valley have also shown high phenolic compounds content, especially tannins which making them suitable for aging in wood (de Andrade, \& Nascimento, L. S. Do, Pereira, G. E., Hallwass, F., \& Paim, A. P. S., 2013; Lucena et al., 2010).

The influence of wood on wine aging is an interesting and controversial subject. Traditionally, oak wood is used because it is flexible enough to mount barrels, with little porosity, an acceptable level of tannins and mild aromatic impact. The oak barrels not only add aromas and tannins to the wine making it more complex, but also, because of their porosity, they allow the drink to breathe, develop and mature (Jackson, 2014).

Among the best species suited to the manufacture of barrels are the Quercus alba, also called American oak, Quercus robur and Quercus petraea, found in most of the French forests (Lona, 1996). While the American oak gives an aromatic note reminiscent of coconut and

\footnotetext{
* Corresponding autor at: Rua Monteiro Lobato 80, CEP 13083-862, Campinas, SP, Brazil.

E-mail address: natalia.manzatti@gmail.com (N.M.M. Alencar).
} 
vanilla to the wine, the French oak, which is considered more sophisticated, passes to the wine different aromas that resemble coffee, spices and butter (Amerine \& Singleton, 1984; Jackson, 2008). The geographic origins and species of wood (American: Quercus alba or French: Quercus petrae) improve the volatile profile and implied in different sensory characteristics; it could be more accentuated when the toasting chips are used (Schumacher, Alañón, Castro-Vázquez, Pérez-Coello, \& DíazMaroto, 2013). The degree of toast of the wood may also contribute with roasted and smoked aromas (Koussissi et al., 2009). Wines aged in medium-toasted oak have richer vanilla and wood aromas, while wines aged in oak with light toast are characterized by vegetal aroma and have less intense sweet taste and higher astringency when compared to medium-toasted oak (Chira \& Teissedre, 2015; González-centeno, Chira, \& Teissedre, 2016).

Brazilian wineries and most of new world need to import oak barrels from North America and Europe, which has an impact on the cost of producing wine. An alternative is the use of oak chips, an economically more viable alternative for wines to gain or increased the complexity and aromas of the wood without suffering great impact of cost (Eiriz, Oliveira, \& Clímaco, 2007). The chips can be put in contact with the wine in several stages, from the fermentation of the must until the wine is ready. In addition, they are either used in place of the aging period in barrels, or to supplement it, in cases when more intense influence of wood is desired. Although somewhat controversial, it is a valid artifice and, when used properly and consciously, satisfactory results may be obtained (Koussissi et al., 2009; Pizarro, Rodríguez-Tecedor, EstebanDíez, Pérez-Del-Notario, \& González-Sáiz, 2014; Tao, García, \& Sun, 2014).

Notwithstanding investments in viticulture and technology, the per capita consumption of wine in Brazil remain low, reaching 21, as compared to other South-American neighbors such as Chile (14.71) and Argentina (31.6) (Almeida, Bragagnolo, \& Chagas, 2015). Moreover, data from the Instituto Brasileiro do Vinho showed a decrease of $7.94 \%$ in the consumption of wines produced locally between 2016 and 2017, while wine imports rose by $39.1 \%$ (Ibravin \& Do, 2017). This raises a question: do Brazilian consumers actually reject national wine and for what reasons? (e.g., sensory quality, product image, stereotypes?).

From the sensory point of view, traditional sensory methods such as Quantitative Descriptive Analysis (QDA) and acceptability testing (e.g, hedonic and JAR scales) have been used to reveal and quantify sensory characteristics as well as preferences and acceptability to wine (Behrens \& Silva, 2000; Behrens, Silva, \& Wakeling, 1999; Biasoto, Netto, Marques, \& da Silva, 2014; Villanueva \& Da Silva, 2009). Though affective methods are the most suitable way of assessing consumers' preference, the traditional descriptive methods, despite their validity and robustness for describing and quantifying sensory characteristics by means of trained or expert panels, demand a lot of time and effort to produce results (Cadena et al., 2014; Dehlholm, Brockhoff, Meinert, Aaslyng, \& Bredie, 2012; Antúnez, Vidal, Saldamando, Giménez, \& Ares, 2017). In this sense, novel and "quick" methods have gained interest among sensory and consumer scientists in the recent years like flash profile, napping and CATA (Check-all-that-apply) (Valentin, Chollet, Lelièvre, \& Abdi, 2012).

CATA has shown as prominent tool to describe and differentiate samples in relation to their specific characteristics, helping in the identification of consumers' perceptions and preferences for food products and beverages (Ares, Deliza, Barreiro, Giménez, \& Gámbaro, 2010), for its simplicity and ease to be applied with trained or untrained assessors (Ares, 2015; Meyners \& Castura, 2014). CATA questions consist of a preselected list of terms from which respondents select all that they consider appropriate to describe a product. The data can be further analyzed by non-parametric tests based on the Chi-square distribution or correspondence analysis (CA) to obtain a perceptual map (Meyners, Castura, \& Carr, 2013).

Vidal, Giménez, Medina, Boido, and Ares (2015) used CATA list comprising 44 terms to assess how consumers describe astringency in red wine. Results showed that, although consumers' vocabulary seemed limited, they could accurately describe wine astringency being this sensation mainly related to dry and roughness sensations. In another research involving wine consumers in China, Corsi, Cohen, Lockshin, and Williamson (2017) performed an acceptance test along with a CATA to test the equivalence of flavor descriptors typically used for wine in Western countries with local descriptors for Chinese consumers. Generic descriptors (e.g., oaky, astringent, fruity, etc.) terms were used approximately three times more often than specific (e.g. vanilla, plum, green bell pepper) terms, and local specific descriptors were not selected consistently more often than the non-local (western) specific descriptors. These studies demonstrate the importance of assessing how the consumer perceives and describe wine. The CATA methodology is quick, simple, could be applied with trained or untrained assessors, and without the need of replication. The information generated is valid for the development of new products, and it is useful in conjunction with classic methodologies as sensory profile to provide more accurate results (Ares, 2015; Meyners \& Castura, 2014).

The purpose of the present study was to determine the descriptive sensory profile and to evaluate the consumer perception of Syrah wine from the San Francisco Valley aged with and without (control) addition of American and French oak chips. This research is justified, since Brazil has been emerging as a producer in the world scenario and much is due to agronomic and technological research that make Brazilian wine more competitive. However, research that evaluates the sensory quality of Brazilian wine is fundamental to guide the decision-making of local producers, particularly regarding the quality and marketing of the product.

\section{Materials and methods}

\subsection{Winemaking}

Syrah grapes from Embrapa Tropical Semi-Arid vines situated at $09^{\circ}$ 09 'S, $40^{\circ} 22$ 'W, $365.5 \mathrm{~m}$ in the São Francisco Valley, Pernambuco, Brazil were harvested manually in the vineyard on July 2015 in their optimal ripening stage $\left(25.99^{\circ} \mathrm{Brix}\right)$. After the harvest, the grapes were kept in a cold chamber for $10 \mathrm{~h}$ at $10^{\circ} \mathrm{C}$ to decrease and stabilize the temperature. Sequentially, the grapes were destemmed and lightly crushed with the aid of a commercial destemmer and were transferred to a stainless-steel tank. Six batches of grapes were processed in a semiindustrial scale; maceration started with the addition of potassium metabisulfite $\left(0.10 \mathrm{~g} \mathrm{~L}^{-1}\right)$ and pectinolytic enzyme Everinetec $^{\circledast}$ $\left(0.008 \mathrm{~mL} \mathrm{~L}^{-1}\right)$. Commercial yeast Maurivin Consistent Quality ${ }^{\circledR}$ Saccharomyces cerevisiae $\left(0.20 \mathrm{~g} \mathrm{~L}^{-1}\right)$ and activating Coatec ${ }^{\circledR}$ ammonium phosphate $\left(0.20 \mathrm{~g} \mathrm{~L}^{-1}\right)$ were added to the must to start the alcoholic fermentation under controlled temperature $\left(24^{\circ} \mathrm{C} \pm 2{ }^{\circ} \mathrm{C}\right)$ and $4 \mathrm{~g} \mathrm{~L}^{-1}$ of American and/or French oak chips were added in the must. For the wines that receive the oak chip in the alcoholic and malolatic fermentations, chips were substituted for new ones prior to the malolactic fermentation. The oak chips were placed in nylon bags positioned at the center of the tank.

The oak chips tested were French oak chips (France/AEB-group) and it was $2.5 \times 5.0 \times 0.5 \mathrm{~cm}, 100 \%$ wood Quercus Petreae, with higher toasted. American oak chips (Italy/Everintec) dimensions was $2.5 \times 2.0 \times 1.0 \mathrm{~cm} ; 100 \%$ wood Quercus alba, with medium toast. The quantities of the chips and degree of toast were determined according to the manufacturer's specifications and preliminary studies in the literature (Gordillo, Cejudo-Bastante, Rodríguez-Pulido, González-Miret, \& Heredia, 2013; García-Carpintero, Sánchez-Palomo, \& González Viñas, 2014).

The maceration processes with the skins and seeds were carried for all up to a maxi mean of 30 days. At this stage, the open pumping of $40 \%$ of the total volume of the tank was daily made, in order to promote homogenization. In the end of the alcoholic fermentation (20 days) was determined by measuring the density in electronic balance hydrostatic 
model Super Alcomat (Gibertini, Milan, Italy), the skins and seeds were separated from the wine and pressed through pressing at $50 \mathrm{bar}$ (Control Tech Automação). The wines were placed in a glass carboy container (201) closed with cylindrical airlock glass valves with floating bubbler and the malolactic fermentation started naturally and it was temperature-controlled $\left(18^{\circ} \mathrm{C} \pm 1{ }^{\circ} \mathrm{C}\right)$. Then, the wines received the oak chips; the treatments that received oak chips in the alcoholic fermentation had the chips replaced by new ones. The free concentration of sulfur dioxide levels in red wines were adjusted in $50 \mathrm{mg} \mathrm{L}^{-1}$ at the end of the malolactic fermentation, before starting stabilization (Ribereau-Gayon \& Peynaud, 1980). The end of the malolactic fermentation was checked by paper chromatography (to determine the presence of malic acid) and the wines were further stabilized using Stabigum ${ }^{\circledast}$ AEB Group (mixture of gum arabic and metatartaric acid) $\left(0.4 \mathrm{~g} \mathrm{~L}^{-1}\right)$, in cold chamber, to induce tartaric stabilization. At the end of this stage, the wine was subjected racking retain yeasts and suspended particles. The wine was bottled $(750 \mathrm{~mL})$, in bottles previously filled with nitrogen to prevent oxidation, and stored in a cellar at $18{ }^{\circ} \mathrm{C}$ in horizontal position for 30 days until the analyses.

The color of the wines was determined using the CIELab and CIEL ${ }^{*} \mathrm{C}$ *h systems where the parameters L* (luminosity), a* (green-red), b*(blue-yellow), h (hue angle) and $C *$ (chroma) were measured in a Hunter Lab model Color Quest II spectrophotometer (Hunter Associates Laboratory, Reston, VA, USA). The equipment was calibrated with the illuminant D65, $10^{\circ}$ hue angle and the RSIN calibration mode (Minolta, 1994). Finally, pH, total acidity, volatile acidity, alcoholic content, free and total sulfur dioxide, and reducing sugars were determined (triplicates) for all the samples according to the standard methods Association of Official Analytical Chemists (2007).

Table 1 summarized the winemaking and presents the physicochemical characteristics of the wines.

\subsection{Sensory evaluation}

The protocols of the sensory studies were approved by the Ethics Committee of the University of Campinas, under the protocol (CAAE $n^{\circ}$ $34,586,014.9 .0000 .5404)$. All the subjects were properly informed of the objectives of the research and gave signed consent for their participation.

\subsubsection{Descriptive sensory profiling}

The sensory profile of the wines was performed in the Sensory Analysis Laboratory of Embrapa Semi-arid. Candidates for assessors were preselected based on recognition of basic tastes and aromas (Biasoto et al., 2014; Sánchez-Palomo, Trujillo, Ruiz, \& Viñas, 2017). Afterwards, they were trained using the terms in the in Wine Aroma Wheel ${ }^{\circledR}$ to memorize the types of aromas regularly found in red wines (Noble et al., 1987). The panelists were asked to identify each reference and find the identical pattern in a second subset containing the same scents, but coded with different three-digit numbers. Thus, the Wine Aroma Wheel ${ }^{\circledR}$ standards were evaluated in several sessions until panelists correctly identified $100 \%$ of the standards presented. Finally the 12 assessors were chosen according to their ability of correctly identified the aromas.

The Kelly's Repertory Grid Method was applied to generate a list of descriptors (Moskowitz, 1983). For each session, were presented three samples and the assessors had to describe similarities and differences regarding appearance, aroma, taste, and mouthfeel. In subsequent sessions, the panel discussed the descriptors and consensually defined the 17 attributes that characterized the wines, their verbal definitions and references as shown in Supplementary Table S1.

Ten training sessions ( $1 \mathrm{~h}$ each) were performed for the assessors to learn the attributes having references of maximum and minimal intensity for each established attribute (Table S1). Also during the training, a 9-cm linear unstructured scale was presented to the panel as an instrument for measuring the intensity of each sensory attribute

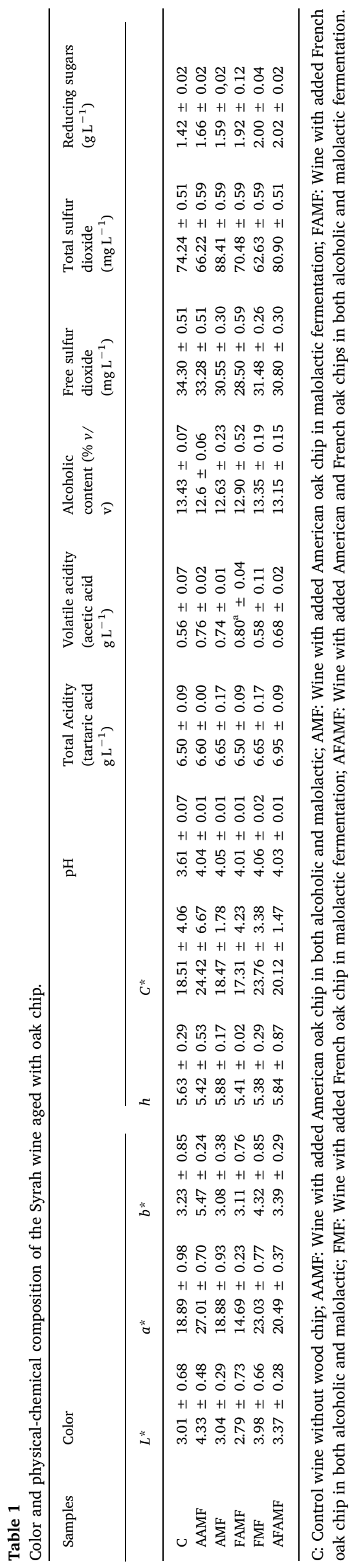


Table 2

Attribute mean scores for appearance, aroma, taste/flavor and mouth sensations for each sample of Syrah wine by the trained sensory panel $\left(\mathrm{N}_{1}=10\right.$ assessors. $\mathrm{N}_{2}=3$ repetitions/sample).

\begin{tabular}{|c|c|c|c|c|c|c|c|}
\hline Descriptors & $\mathrm{C}$ & AAMF & $\mathrm{AMF}$ & FAMF & FMF & AFAMF & $L S D^{*}$ \\
\hline \multicolumn{8}{|l|}{ Appearance } \\
\hline Wine Color & $6.06^{\mathrm{ab}}$ & $5.39^{\mathrm{b}}$ & $6.27^{\mathrm{a}}$ & $5.74^{\mathrm{ab}}$ & $5.94^{\mathrm{ab}}$ & $6.32^{\mathrm{a}}$ & 0.81 \\
\hline Brightness & $5.70^{\mathrm{a}}$ & $5.60^{\mathrm{a}}$ & $5.16^{\mathrm{a}}$ & $5.21^{\mathrm{a}}$ & $5.47^{\mathrm{a}}$ & $5.14^{\mathrm{a}}$ & 0.91 \\
\hline \multicolumn{8}{|l|}{ Aroma } \\
\hline Aromatic intensity & $4.07^{\mathrm{b}}$ & $5.35^{\mathrm{a}}$ & $4.63^{\mathrm{ab}}$ & $4.70^{\mathrm{ab}}$ & $4.64^{\mathrm{ab}}$ & $5.62^{\mathrm{a}}$ & 1.00 \\
\hline Alcoholic & $3.38^{\mathrm{a}}$ & $3.27^{\mathrm{a}}$ & $3.18^{\mathrm{a}}$ & $3.14^{\mathrm{a}}$ & $3.34^{\mathrm{a}}$ & $3.30^{\mathrm{a}}$ & 0.80 \\
\hline Coffee & $0.73^{\mathrm{ab}}$ & $1.17^{\mathrm{a} . \mathrm{b}}$ & $1.22^{\mathrm{a}}$ & $0.64^{\mathrm{ab}}$ & $0.44^{\mathrm{b}}$ & $0.78^{\mathrm{ab}}$ & 0.76 \\
\hline Woody & $1.35^{\mathrm{d}}$ & $5.20^{\mathrm{a}}$ & $4.14^{\mathrm{ab}}$ & $2.58^{\mathrm{c}}$ & $2.68^{c}$ & $3.43^{\mathrm{bc}}$ & 1.10 \\
\hline Sweet/caramelized & $1.92^{\mathrm{a}}$ & $2.22^{\mathrm{a}}$ & $1.71^{\mathrm{a}}$ & $1.73^{\mathrm{a}}$ & $1.60^{\mathrm{a}}$ & $1.99^{\mathrm{a}}$ & 0.78 \\
\hline Vegetal & $1.48^{\mathrm{a}}$ & $1.03^{\mathrm{a}}$ & $1.24^{\mathrm{a}}$ & $1.38^{\mathrm{a}}$ & $1.46^{\mathrm{a}}$ & $0.77^{\mathrm{a}}$ & 0.74 \\
\hline Spicy & $1.23^{\mathrm{a}}$ & $1.14^{\mathrm{a}}$ & $1.29^{\mathrm{a}}$ & $1.21^{\mathrm{a}}$ & $1.30^{\mathrm{a}}$ & $1.48^{\mathrm{a}}$ & 0.64 \\
\hline \multicolumn{8}{|l|}{ Taste / Flavor } \\
\hline Taste persistence & $3.98^{\mathrm{a}}$ & $3.67^{\mathrm{a}}$ & $3.64^{\mathrm{a}}$ & $4.23^{\mathrm{a}}$ & $4.11^{\mathrm{a}}$ & $3.78^{\mathrm{a}}$ & 0.99 \\
\hline Sweetness & $0.78^{\mathrm{b}}$ & $0.96^{\mathrm{b}}$ & $1.01^{\mathrm{b}}$ & $1.14^{\mathrm{b}}$ & $1.84^{\mathrm{a}}$ & $1.12^{\mathrm{b}}$ & 0.51 \\
\hline Bitterness & $2.30^{\mathrm{a}}$ & $1.71^{\mathrm{a}}$ & $2.03^{\mathrm{a}}$ & $1.97^{\mathrm{a}}$ & $1.75^{\mathrm{a}}$ & $1.74^{\mathrm{a}}$ & 1.02 \\
\hline Sourness & $2.59^{\mathrm{a}}$ & $2.12^{\mathrm{a}}$ & $2.29^{\mathrm{a}}$ & $2.25^{\mathrm{a}}$ & $2.23^{\mathrm{a}}$ & $2.07^{\mathrm{a}}$ & 0.90 \\
\hline Alcoholic & $3.76^{\mathrm{a}}$ & $3.31^{\mathrm{a}}$ & $3.49^{\mathrm{a}}$ & $3.73^{\mathrm{a}}$ & $3.83^{\mathrm{a}}$ & $3.18^{\mathrm{a}}$ & 0.91 \\
\hline Woody & $1.35^{\mathrm{c}}$ & $3.15^{\mathrm{ab}}$ & $3.5^{\mathrm{a}}$ & $2.63^{\mathrm{ab}}$ & $2.11^{\mathrm{bc}}$ & $2.91^{\mathrm{ab}}$ & 1.21 \\
\hline \multicolumn{8}{|l|}{ Mouth sensations } \\
\hline Astringency & $4.05^{\mathrm{a}}$ & $3.62^{\mathrm{ab}}$ & $3.74^{\mathrm{ab}}$ & $3.82^{\mathrm{ab}}$ & $3.02^{\mathrm{b}}$ & $3.42^{\mathrm{ab}}$ & 1.00 \\
\hline Full-bodied & $3.36^{\mathrm{a}}$ & $3.98^{\mathrm{a}}$ & $3.56^{\mathrm{a}}$ & $3.53^{\mathrm{a}}$ & $3.31^{\mathrm{a}}$ & $3.58^{\mathrm{a}}$ & 0.97 \\
\hline
\end{tabular}

Means in the same line showing common letters are not significantly different $(P \leq .05)$ according to Tukey's test. "Least significant difference. C: Control wine without wood chip; AAMF: Wine with added American oak chip in both alcoholic and malolactic; AMF: Wine with added American oak chip in malolactic fermentation; FAMF: Wine with added French oak chip in both alcoholic and malolactic; FMF: Wine with added French oak chip in malolactic fermentation; AFAMF: Wine with added American and French oak chips in both alcoholic and malolactic fermentation.

(Associação Brasileira de Normas Técnicas, 1998; Behrens \& Silva, 2000).

After the training, a final selection of the panelists was carried out and the panel evaluated all the samples in triplicate, using a descriptive ballot comprising the 17 attributes and the respective rating scales. Analysis of Variance (ANOVA) were performed for each assessors for all the attributes, containing the following sources of variation: sample and repetition, in order to evaluate the discriminative power and the repeatability of the candidates in the trial of wines. Ten individuals showing adequate discriminative power $\left({ }_{\mathrm{p}} \mathrm{F}_{\text {wine }} \leq 0.30\right)$, reproducibility $\left({ }_{\mathrm{p}} \mathrm{F}_{\text {replication }} \geq 0.05\right)$ and consensus with the rest of the panel for at least $80 \%$ of the 17 descriptors were selected to take part of the final descriptive panel (Damásio \& Costelli, 1991).

For the develop the wines sensory profiling, $30 \mathrm{ml}$ of wine were served at $18^{\circ} \mathrm{C}$, in ISO (3591) wine glasses, coded with three-digit numbers, and covered with watch glass to prevent the loss of volatile aroma. The evaluations were carried out in individual booths under white illumination and the samples were presented monadically in a completely randomized blocks design. The assessors were oriented to evaluate the wine with attention to the attributes and respective references of intensity showed in the training sessions. Furthermore, the assessors were oriented to rinse the palate with distilled water (20s) and crackers between the samples. Each test session was composed by the analysis of six wines, however, to avoid sensory fatigue, before the evaluator test the fourth sample received a $20 \mathrm{~min}$ interval. In final, each assessor $(N=10)$ evaluated six different samples in three repetitions.

Principal component analysis (PCA) was accomplished using significant means of the sensory scores and the data of the physical-chemical analyses through a Pearson correlation matrix. The goal of the PCA was summarized the sensory data and to uncover underlying dimensions that help to explain the relationship between the processes variables and the resulting sensory profile of the wines. The procedure was performed using the package FactoMiner for $\mathrm{R}$ (Lê, Josse, \& Husson, 2008).

\subsubsection{Consumer testing}

A total of 129 Brazilian consumers (aged between 21 and 50 years old, 49\% male and 51\% female) evaluated the samples in four different settings: two wine stores, a wine-lovers group and the Sensory and Consumer Science Laboratory at the School of Food Engineering of the University of Campinas, Brazil. About $80 \%$ of the participants stated to consume at least one glass of wine on a weekly basis.

Wines (Table 1) were monadically served in $30 \mathrm{~mL}$ samples, in wine glasses coded with three - digit random numbers following a balanced presentation order to minimize first-order and carry over effects (Macfie, 1989). Water and unsalted crackers were available to clean the palate.

Liking was assessed using a 9-point structured scale anchored at the extremes by "disliked very much" and "liked very much" (Stone \& Sidel, 2004). Then, they completed the CATA question comprising 21 terms related to sensory attributes (persistence of flavor, alcoholic, equilibrate, dryness, sourness, sweetness, bitterness, light red color, deep red color, young, body, watery, bouquet, herbaceous, red fruit, vanilla, woody, spicy, vegetal, aromatic, grape). These terms were chosen considering the descriptors elicited by the trained accessors and other terms selected from literature (Biasoto et al., 2014; Izquierdo-Cañas, Mena-Morales, \& García-Romero, 2016; Schumacher et al., 2013). The order in which the CATA terms appeared in the list were balanced for each consumer (Antúnez, Vidal, de Saldamando, Giménez, \& Ares, 2017; Ares, Barreiro, Deliza, Giménez, \& Gámbaro, 2010; Ares \& Jaeger, 2013).

Hierarchical Cluster on Principal Components (HCPC) was used to identify groups of consumers with similar acceptance patterns (Husson, Josse, \& Pagès, 2010). The procedure basically consisted on a PCA through a Pearson correlation matrix performed on the acceptance data (matrix of the 129 consumers on the six wines) followed by hierarchical clustering (Ward's method) performed on the principal components of the PCA (i.e. the scores scaled to the associated eigenvalues. Two clusters of consumers were then identified and characterized by means of demographics.

Cochran's Q test, Correspondence analysis (CA) was used to treat CATA data within each cluster in order to verify how the two groups of consumers described their perceptions of the wines.

The FactoMiner package for R (Lê et al., 2008) was used to perform HCPC whereas Cochran's Q and CA were performed using the feature CATA Analysis on XLStat, Version 2017.4 (Addinsoft, New York, USA).

\section{Results and discussion}

\subsection{Sensory profile}

According to Table 2 , significant differences $(P \leq .05)$ were found with respect to 7 out of 17 attributes describing the wines.

Wine color is influenced by grape ripeness degree that impart higher or lower concentration of monomeric anthocyanins which, in turn, increase the intensity of color of the beverage (Sherman, Greenwood, Villas-Boâs, Heymann, \& Harbertson, 2017). A recent study reported that wines from the São Francisco Valley, due to the environmental conditions of the region are generally rich in anthocyanins, being the malvidin-3-O-glucoside, pigment of the violet-colored, the major compound present (Padilha et al., 2016). The maceration process promote a extraction of phenolic compounds that varies according to time, with anthocyanin extraction being highest during the first 8-10 days of maceration (Ribereau-Gayon, Glories, Maujean, \& Dubourdieu, 2006). Thus in the present study shows that the higher extraction of monomeric anthocyanins (424.73 malvidin-3-glucoside $\mathrm{mg} \mathrm{L}^{-1}$ ) occur on the 20th day of maceration (Alencar et al., 2018), suggesting that prolonged maceration was important to extract monomeric anthocyanins 
Table 3

Liking of the wines and profile of the two consumer segments identified in the HCPC analysis.

\begin{tabular}{|c|c|c|c|}
\hline & & $\begin{array}{l}\text { Cluster } 1 \\
(\mathrm{~N}=60)\end{array}$ & Cluster $2(\mathrm{~N}=69)$ \\
\hline \multirow[t]{7}{*}{ Liking } & $\mathrm{C}$ & 4.4 & 6.6 \\
\hline & AAMF & 5.1 & 6.4 \\
\hline & $\mathrm{AMF}$ & 4.4 & 6.9 \\
\hline & FAMF & 4.4 & 6.5 \\
\hline & FMF & 4.6 & 6.6 \\
\hline & AFAMF & 4.8 & 6.5 \\
\hline & $\mathrm{pF}$ & 0.072 & 0.2490 \\
\hline \multirow{3}{*}{ Gender } & Male & 35 & 28 \\
\hline & Female & 25 & 41 \\
\hline & $\begin{array}{l}\text { Chi-square value } \\
(\mathrm{df}=1)\end{array}$ & $4.04 *$ & \\
\hline \multirow[t]{5}{*}{ Age } & $18-25 \mathrm{YO}$ & 5 & 8 \\
\hline & $26-35$ YO & 19 & 23 \\
\hline & $35-50 \mathrm{YO}$ & 20 & 17 \\
\hline & $>50 \mathrm{YO}$ & 16 & 21 \\
\hline & $\begin{array}{l}\text { Chi-square value } \\
(\mathrm{df}=3)\end{array}$ & 1.34 & \\
\hline \multirow[t]{5}{*}{ Wine intake } & Daily & 5 & 12 \\
\hline & Up to $3 \times$ a week & 26 & 28 \\
\hline & $1 \times$ a week & 16 & 18 \\
\hline & Occasionally & 13 & 11 \\
\hline & $\begin{array}{l}\text { Chi-square value } \\
(\mathrm{df}=3)\end{array}$ & 2.66 & \\
\hline
\end{tabular}

* Significant $(P<.05)$; HCPC: Hierarchical Cluster on Principal Components; C: Control wine without wood chip; AAMF: Wine with added American oak chip in both alcoholic and malolactic; AMF: Wine with added American oak chip in malolactic fermentation; FAMF: Wine with added French oak chip in both alcoholic and malolactic; FMF: Wine with added French oak chip in malolactic fermentation; AFAMF: Wine with added American and French oak chips in both alcoholic and malolactic fermentation.

and intensify the color of the wine. On the other hand, the use of the oak chip in the fermentation process also increased the concentration of phenolic compounds affecting the wine color. Therefore, the amount of $5 \mathrm{~g} / \mathrm{L}$ chip used promote a significant increase in the red color of the wines compared to the amount of $2 \mathrm{~g} / \mathrm{L}$ (Liu et al., 2016).

Despite the significant differences $(P \leq .05)$ in color intensity as measured by the trained panel, a short variation in the mean ratings was observed. The wine AAMF presented lower values of color intensity, and differed of AMF and AFAMF, that showed of higher values of wine color intensity, suggesting that the oak species and contact time could affect the color of the beverage. In addition, no significant difference $(P>.05)$ was observed in the brightness of the wines; thus, the chip addition might not be an important factor to this attribute as well.

The aroma and flavor descriptors that showed significant differences between the samples $(P \leq .05)$ were coffee and woody aromas, woody flavor and sweetness. Table 3 show that the oak species influenced in the perception of these descriptors. Wines added with oak chips, as expected, presented higher aromatic intensity as compared to the control wine. The authors identified that when oak chips are added at the alcoholic and malolactic fermentations, the aromatic intensity increased compared to the samples that were fermented with oak chip only during the malolactic fermentation. However, medium-toast American oak chips added higher coffee and woody notes to the wine, differently from the wines aged with high-toasted French oak which were characterized by higher perception of sweetness.

Toasted oak chips are capable to changing wine aroma by adding of compounds such as phenols (e.g., vanillin, eugenol and guaiacol), aldehydes (e.g., furfural and syringaldehyde), lactones, furanic compounds (Arapitsas, Antonopoulos, Stefanou, \& Dourtoglou, 2004; Gómez García-Carpintero et al., 2014), and these compounds impart aromas of wood, nuts, vanilla and clove (Cano-López, Bautista-Ortín, Pardo-Mínguez, López-Roca, \& Gómez-Plaza, 2008; Schumacher et al., 2013) On the other hand, wines elaborated with oak chips during alcoholic fermentation may suffer a decrease in some aromas associated with floral, fruity, citric and spicy notes (García-Carpintero, Gallego, Sánchez-Palomo, \& Viñas, 2012). In this research a higher intensity of aroma, along with greater intensities of notes as woody and coffee were found in Syrah wines elaborated with American oak chips addition. As expected, the $\mathrm{C}$ wine showed the lowest intensity of all aromas descriptors evaluated compared to aged wines, in agreement with CanoLópez et al. (2008) who found that oak chip addition improve the aroma profile and modify the sensory descriptors as compared to the control wine (without chips).

Astringency was more intense in the control wine (C), and significantly less perceived in the sample FMF $(P \leq .05)$ added with French oak chips during the malolactic fermentation, which suggests that both the chips have diminished the perception of astringency. In general, both American and French oak chips had little impact on astringency, differently from García-Carpintero et al. (2012) report that oak chips promoted higher astringency in wines because the extraction of phenolic compounds. The main phenolic compound responsible for astringency in wine is procyanidin B3; however, the aging process in wood causes modification in the phenol structure, resulting in softening of the wine tannins (Ribereau-Gayon et al., 2006). Moreover, oak chips may also impart a sensation of sweetness resulting from the triterpenoids from the oak wood (Axel Marchal, Cretin, Sindt, Waffo-Téguo, \& Dubourdieu, 2015). In the present study, the wine added with French chip during malolactic fermentation presented a sweeter taste as compared to the other samples. This result was expected, since sweetness in the increase during maturation, which could be explained by the extraction of sweet compounds from oak; this phenomenon depends on the nature of the aging (Marchal, Pons, Lavigne, \& Dubourdieu, 2013). No significant differences $(P>.05)$ were observed regarding the attributes, sweet/caramelized, vegetal and spicy aroma, taste persistence, bitterness, acidity, and alcoholic flavor. In fact, as observed in Table 1 the alcohol content was similar among all the wines as they were produced with the same musts and under similar processes.

Summarizing the descriptive data and color and physical-chemical parameters (Tables 1 and 2), the first three principal components obtained from the PCA on the discriminant attributes' mean ratings accounted for $82.64 \%$ of the original variance and the biplot on Fig. 1 depict the similarities and differences among the wines as a function of the fermentative processes and chips additions. According to Fig. 1 the control wine (C) presented a sensory and physical-chemical profile distinct compared to the other wines evaluated that fermented with oak chip regardless of the specie of oak used and the stage of fermentations were added.

PC $1(32.12 \%)$ had greater contribution of aromatic intense, woody aroma, $\mathrm{L}, \mathrm{a}^{*}, \mathrm{~b}^{*}, \mathrm{C}^{*}$ and $\mathrm{pH}$, and wine color. This dimension showed that the aged wine with addition of oak chip and of the type of oak applied influenced in the wine aroma and color. The wine control (C) was located in opposite side of the sample AAMF in the PC1. Observed in the PCA that samples AAMF was characterized by aromatic intensity and woody aroma, while the wine $C$ presented a lower intensity of these descriptors. PC2 (27.47\%) was related to coffee aroma, woody flavor, h, volatile acidity, and total sulfur dioxide (positive side) and alcoholic content (negative side).The samples located in the positive side (AMF, AFAMF, AAMF and FAMF) was characterized by the woody flavor and coffee aroma. In this way, the higher time of contact of American oak chip promote a higher intensity of this descriptors. PC3 (20.03\%) were describe as sweetness, total acidity, reducing sugar, free sulfur dioxide and astringency. Reducing sugar correlated with sweetness, and the samples fermented with the French chip (FMF, FAMF e AFAMF) highlight in these attributes, that was located in positive side of the PC3. However, what seems to explain the significantly greater intensity of FMF sweetness would be the lower intensity of astringency of this wine, differing significantly from the control samples. The wine $\mathrm{C}$ is close to the astringency vector, which is in position to sweetness and reducing sugar in PCA. 







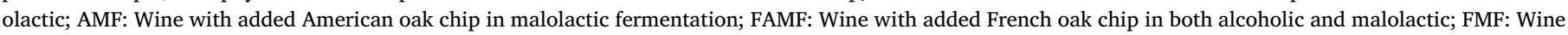



\subsection{Consumer testing}

HCPC on the liking data revealed two clusters of consumers, as shown in Table 3. It is interesting to note that the most of the consumers participating in the sensory test stated consuming wine regularly ( $1 \mathrm{x}$ a week or more) and $61.2 \%$ were between 26 and 50 years old, that is to say, pertaining to the Millenials and Generation-X consumers. As these individuals were recruited in liquor shops and wine-lovers groups, the sample somewhat reflects a trend verifying in traditional wine markets like the USA and Australia, where wine intake is in increase among the Young, especially the female consumers (Bruwer, Saliba, \& Miller, 2011).

Cluster $1(\mathrm{~N}-60)$ comprised consumers who disliked the Syrah wines aged with oak chips, given that the mean acceptance scores ranged between 4.4 and $5.1(P>.05)$. On the other hand, the consumers of cluster $2(N=69)$ liked the wines, since the mean acceptance scores were between 6.4 and $6.9(P>.05)$. However, gender was a factor of differentiation between the clusters: there were significantly more male consumers in cluster 1 , while in cluster 2 women were a significant majority $(P \leq .05)$.

Analyzing the CATA data within each cluster helps to understand how Syrah wines aged with oak chip were perceived. In cluster 1, only four of the 21 CATA terms showed association with the wine samples $(P \leq .05)$ according to the Cochran's $Q$ test and then only these terms, namely vanilla, woody, deep red color and watery, were then used in CA (Fig. 2A).

The wines added with American oak chips were more associated with woody (especially AFAMF and AAMF), whereas FMF was associated with vanilla and FAMF was associated with watery. C and AMF were associated with deep red color.

Cluster 2, on the other hand, also associated the wines with the terms woody, watery and deep red color, but also with other terms like spicy, body and bouquet. CA (Fig. 2A) shows that the wines added with American oak chips (AAMF, AFAMF and AMF) stand out from the rest because they are similarly perceived as woody, spicy and bodied. On the other hand, wines with French oak (FMF and FAAMF) were associated with watery, while C (control) was perceived as having more bouquet.

For the foregoing, results suggest that oak chip has influenced the wine aroma, thus the expert panel identified in the aged wines a woody and coffee characters. In contrast, the consumers were able to perceive differences among the intensity of the woody note in the aged wines and in others as spicy and vanilla according with CATA data, however, they like the aged Syrah wines as much the control wine. The study of Bruwer et al. (2011) reports that, from a sensory viewpoint, fruit flavor and aromas are the most important characteristics of a wine valued by consumers. However, while males prefer aged characters of wine, females value oaky and woody aromas these are aged characters also, which is in line with the results presented herein.

The sensory descriptive profile produces a greater detail of the characteristics of the products, however it is a methodology that on average is developed in 2 months or more and requires trained assessors to analyze the samples (Cadena et al., 2014). On the other hand, the CATA method, which has been widely used in sensory and consumer science, the same attributes obtained in the sensorial profiles can be used in a way that consumers can mark the terms that best characterize the product according to their perception (Dos Santos et al., 2015). These methodologies are considered different in their ability to detect differences between samples; however, when comparing the results, it may be noted that the techniques provide similar information. Thus, in this study is possible to observe that the DA analyses addressed in a detailed the impact of oenological technologies and promoted a precisely quantified of their effects in the Syrah wine quality. By DA was possible to conclude that both the specie of oak chip and the time of chip addition influenced in the wine sensory profile. On the other hand, CATA analysis revealed that consumers, especially those from cluster 2 that liked of the wines, were more sensitive to specie of oak chip used than time duration that the chips were applied to age the wine.

Finally, a major limitation of this study is that it was intended to assess the effect of chip addition as a substitute for the traditional oak barrels in Syrah wine. Nonetheless, other vines are cultivated in the São Francisco Valley region and having potential for aged wine production. Alternatives should also be further investigated such as the combined use of oak chips (with different degrees of toasting) and micro-oxigenation. Another limitation is that only Brazilian consumer assessed the wines and, therefore, subsequent studies should focus on international markets as long as Brazilian wineries intend to promote their products abroad. Anyway, the findings presented herein are of value to 


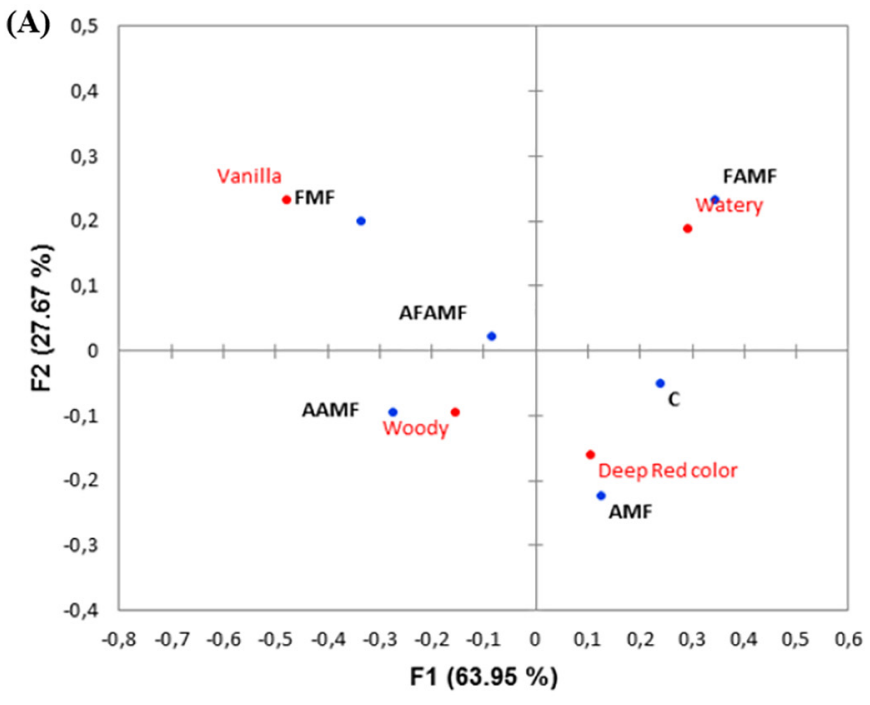

- Attributes - Products

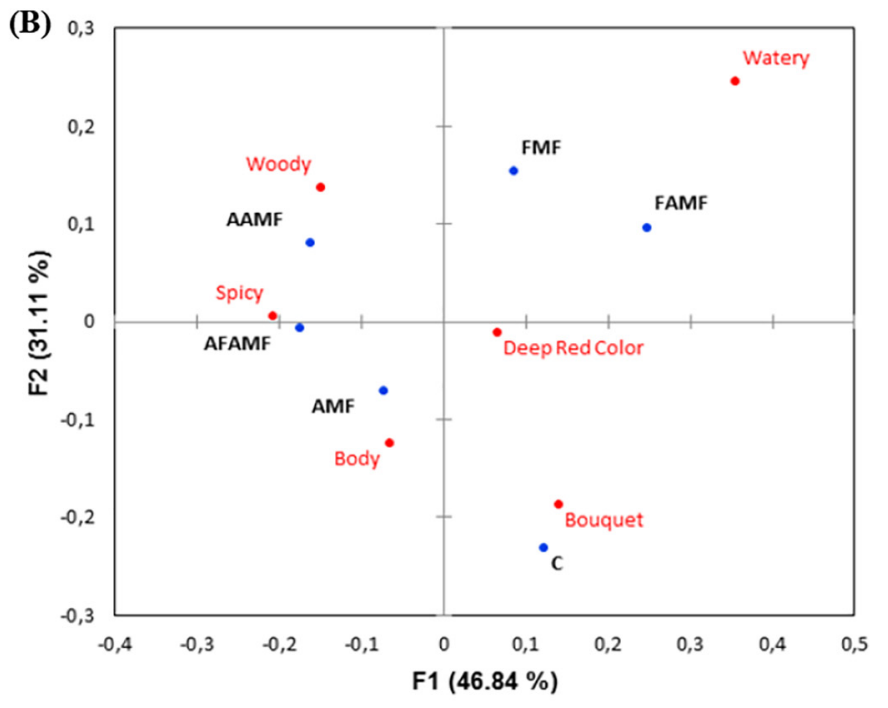

- Attributes - Products

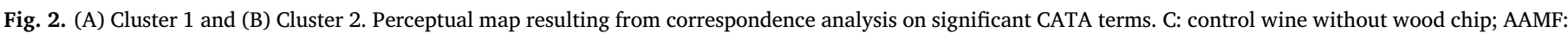



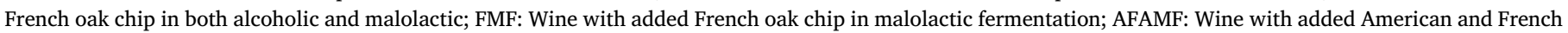
oak chips in both alcoholic and malolactic fermentation.

researchers, wine industry and other wine distribution channel members, as it provides insights into the use of oak chip to produce quality wines in the emerging tropical regions and how consumers make sense of them through a sensory viewpoint.

\section{Conclusions}

The aged of Syrah wines with American and French oak chips influenced the sensory profile of the beverage. Thus, results from sensory descriptive analyses revealed that American oak chips imparted higher intensities of woody and coffee aromas to the wine, while French oak slightly decreased astringency and increased the perception of sweetness. These differences not affected the acceptance of the Syrah wines. Two segments of consumers showed different attitudes: one group comprised mostly of men $(N=60)$ rejected all samples, while the other one $(N=69)$ liked them and comprised mostly of women. The treatments tested in the study provide important information for winemakers regarding the potential of use of oak chips rather than traditional (and more expensive) barrels to age wines, producing quality wines well accepted by consumers. Further study with addition of larger amounts of the oak chips and with different degrees of toasting would be interest, since the wood contribute to a greater transfer of aromatic compounds, enhancing aroma and flavor complexity of the beverage.

\section{Authors' contributions}

N.M.M.A., A.T. B.M., J.H.B. conceived and planned the study. N.M.M.A and A.P.A.B. participated of the winemaking process. N.M.M.A., T.R.G. and B.B. contributed to data collection and analysis. All authors contributed to this article.

\section{Acknowledgements}

The authors are grateful to Embrapa Semiárido for the assistance during the winemaking and analysis; Coordenação de Aperfeiçoamento de Pessoal de Nível Superior (CAPES) for NMMA's, BB's and TRG's scholarships. This work was supported by Embrapa (grant numbers:
03.13.06.017.00.00) and FACEPE (grant numbers: Project: APQ-09215-07/14). The authors are grateful to Nog consulting, Espaço Thomson consulting and Decanter Enoteca store for the assistance on the sensory analysis. The authors are also grateful to the tasters.

\section{Conflicts of interest}

The authors declare no conflicts of interest.

\section{Appendix A. Supplementary data}

Supplementary data to this article can be found online at https:// doi.org/10.1016/j.foodres.2018.07.052.

\section{References}

Alencar, N. M. M., Cazarin, C. B. B., Corrêa, L. C., Maróstica Junior, M. R., Biasoto, A. C. T., \& Behrens, J. H. (2018). Influence of maceration time on phenolic compounds and antioxidant activity of the Syrah must and wine. Journal of Food Biochemistry, 42(2), 1-11. https://doi.org/10.1111/jfbc.12471.

Almeida, A. N., Bragagnolo, C., \& Chagas, A. L. S. (2015). A Demanda por Vinho no Brasil : elasticidades no consumo das famílias e. Revista de Economia e Sociologia Rural, 53(3), 433-454. https://doi.org/10.1590/1234-56781806-9479005303004.

Amerine, M. A., \& Singleton, V. L. (1984). Wine an introduction (2nd.). Berkeley: University of California Press.

Amine, A., \& Lacœuilhe, J. (2007). Les pratiques de consommation du vin : rôle des représentations et des situations de consommation. XXIIIème Congres International de l'AFM, Aix-les-Bains (pp, 1-24). .

Antúnez, L., Vidal, L., de Saldamando, L., Giménez, A., \& Ares, G. (2017). Comparison of consumer-based methodologies for sensory characterization: Case study with four sample sets of powdered drinks. Food Quality and Preference, 56, 149-163. https:// doi.org/10.1016/j.foodqual.2016.09.013.

Arapitsas, P., Antonopoulos, A., Stefanou, E., \& Dourtoglou, V. G. (2004). Artificial aging of wines using oak chips. Food Chemistry, 86, 563-570. https://doi.org/10.1016/j. foodchem.2003.10.003.

Ares, G. (2015). Methodological challenges in sensory characterization. Current Opinion in Food Science, 3, 1-5. https://doi.org/10.1016/j.cofs.2014.09.001.

Ares, G., Barreiro, C., Deliza, R., Giménez, A., \& Gámbaro, A. (2010). Application of a check-all-that-apply question to the development of chocolate milk desserts. Journal of Sensory Studies, 25, 67-86. https://doi.org/10.1111/j.1745-459X.2010.00290.x.

Ares, G., Deliza, R., Barreiro, C., Giménez, A., \& Gámbaro, A. (2010). Comparison of two sensory profiling techniques based on consumer perception. Food Quality and Preference, 21(4), 417-426. https://doi.org/10.1016/j.foodqual.2009.10.006.

Ares, G., \& Jaeger, S. R. (2013). Check-all-that-apply questions : Influence of attribute 
order on sensory product characterization. Food Quality and Preference, 28, 141-153. https://doi.org/10.1016/j.foodqual.2012.08.016.

Associação Brasileira de Normas Técnicas (1998). Escalas utilizadas em análise sensorial de alimentos e bebidas - NBR 14141. (Rio de Janeiro).

Association of Official Analytical Chemists (2007). Official methods of analysis.

Behrens, J. H., Silva, M., \& Wakeling, I. N. (1999). Avaliação da aceitação de vinhos brancos varietais brasileiros através de testes sensoriais afetivos e técnica multivariada de mapa de preferência interno. Ciência e Tecnologia de Alimentos, 19(2), 214-220.

Behrens, J. H., \& Silva, M. A. P. (2000). Perfil sensorial de vinhos brancos varietais brasileiros através de Análise Descritiva Quantitativa. Ciência e Tecnologia de Alimentos, 20(1), 60-67.

Biasoto, A. C. T., Netto, F. M., Marques, E. J. N., \& da Silva, M. A. A. P. (2014). Acceptability and preference drivers of red wines produced from Vitis labrusca and hybrid grapes. Food Research International, 62, 456-466. https://doi.org/10.1016/j. foodres.2014.03.052.

Brochet, F., \& Dubourdieu, D. (2001). Wine descriptive language supports cognitive specificity of chemical senses. Brain and Language, 77(2), 187-196. https://doi.org/ 10.1006/brln.2000.2428.

Bruwer, J., Saliba, A., \& Miller, B. (2011). Consumer behaviour and sensory preference differences: implications for wine product marketing. Journal of Consumer Marketing, 28(1), 5-18. https://doi.org/10.1108/07363761111101903.

Cadena, R. S., Caimi, D., Jaunarena, I., Lorenzo, I., Vidal, L., Ares, G., ... Giménez, A. (2014). Comparison of rapid sensory characterization methodologies for the development of functional yogurts. Food Research International, 64, 446-455. https://doi org/10.1016/j.foodres.2014.07.027.

Camargo, U. A., de Amorim, F. M., Guerra, C. C., \& Lima, M. V. D. O. (2004). Introdução e avaliação de novas cultivares para vinho no vale do são francisco. I Workshop Internacional de Pesquisa (pp. 103-109).

Cano-López, M., Bautista-Ortín, A. B., Pardo-Mínguez, F., López-Roca, J. M., \& GómezPlaza, E. (2008). Sensory Descriptive Analysis of A Red Wine Aged with Oak Chips in Stainless Steel Tanks or Used Barrels: Effect of The Contact Time and Size Of The Oak Chips. Journal of Food Quality, 31(5), 645-660. https://doi.org/10.1111/j.17454557.2008.00226.x.

Chira, K., \& Teissedre, P. L. (2015). Chemical and sensory evaluation of wine matured in oak barrel: effect of oak species involved and toasting process. European Food Research and Technology, 240, 533-547. https://doi.org/10.1007/s00217-014 2352-3.

Corsi, A. M., Cohen, J., Lockshin, L., \& Williamson, P. (2017). Testing lexical equivalences for wine flavours in emerging markets: Do hawthorns taste like blackberries? Food Quality and Preference, 62, 296-306. https://doi.org/10.1016/j.foodqual.2017.03. 011 .

Damásio, H. M., \& Costelli, E. (1991). Análisis sensorial descriptivo: generación de descriptores y selección de catadores. Revista de Agroquíca Y Tecnologia de Alímentos, 31(2), 165-178.

de Andrade, R. H. S., do Nascimento, L. S., Pereira, G. E., Hallwass, F., \& Paim, A. P. S. (2013). Anthocyanic composition of Brazilian red wines and use of HPLC-UV - Vis associated to chemometrics to distinguish wines from different regions. Microchemical Journal, 110, 256-262. https://doi.org/10.1016/j.microc.2013.04.003.

Dehlholm, C., Brockhoff, P. B., Meinert, L., Aaslyng, M. D., \& Bredie, W. L. P. (2012). Rapid descriptive sensory methods - Comparison of Free Multiple Sorting, Partia Napping, Napping, Flash Profiling and conventional profiling. Food Quality and Preference, 26(2), 267-277. https://doi.org/10.1016/j.foodqual.2012.02.012.

Dos Santos, B. A., Campagnol, P. C. B., Cruz, A. G., Galvão, M. T. E. L., Monteiro, R. A., Wagner, R., \& Pollonio, M. A. R. (2015). Check all that apply and free listing to describe the sensory characteristics of low sodium dry fermented sausages: Comparison with trained panel. Food Research International, 76, 725-734. https://doi. org/10.1016/j.foodres.2015.06.035.

Eiriz, N., Oliveira, J. F. S., \& Clímaco, M. C. (2007). Fragmentos de carvalho no estágio de vinhos tintos. Ciência Técnica Vitivinícola, 22(2), 63-71.

García-Carpintero, E. G., Gallego, M. A. G., Sánchez-Palomo, E., \& Viñas, M. A. G. (2012). Impact of alternative technique to ageing using oak chips in alcoholic or in malolactic fermentation on volatile and sensory composition of red wines. Food Chemistry, 134, 851-863. https://doi.org/10.1016/j.foodchem.2012.02.194.

Gómez García-Carpintero, E., Sánchez-Palomo, E., \& González Viñas, M. A. (2014) Volatile composition of Bobal red wines subjected to alcoholic/malolactic fermentation with oak chips. LWT - Food Science and Technology, 55(2), 586-594. https:// doi.org/10.1016/j.lwt.2013.10.024.

González-Centeno, M. R., Chira, K., \& Teissedre, P. (2016). Ellagitannin content, volatile composition and sensory profile of wines from different countries matured in oak barrels subjected to different toasting methods. Food Chemistry, 210, 500-511. https://doi.org/10.1016/j.foodchem.2016.04.139.

Gordillo, B., Cejudo-Bastante, M. J., Rodríguez-Pulido, F. J., González-Miret, M. L., \& Heredia, F. J. (2013). Application of the differential colorimetry and polyphenolic profile to the evaluation of the chromatic quality of Tempranillo red wines elaborated in warm climate. Influence of the presence of oak wood chips during fermentation. Food Chemistry, 141(3), 2184-2190. https://doi.org/10.1016/j.foodchem.2013.05. 014.

Husson, F., Josse, J., \& Pagès, J. (2010). Principal component methods - hierarchica clustering - partitional clustering: why would we need to choose for visualizing data. Technical report (Retrieved from) http://factominer.free.fr/more/HCPC_husson_ josse.pdf.

Ibravin, I. B., \& Do, V. (2017). Comercialização e Importação. Retrieved November 11, 2017, from http://www.ibravin.org.br/Dados-Estatisticos.

Izquierdo-Cañas, P. M., Mena-Morales, A., \& García-Romero, E. (2016). Malolactic fermentation before or during wine aging in barrels. LWT - Food Science and Technology,
66, 468-474. https://doi.org/10.1016/j.lwt.2015.11.003.

Jackson, R. S. (2008). Wine science: Principles and application. Elsevier (Academic P). California: Elsevier.

Jackson, R. S. (2014). Vineyard practice. Wine Science (pp. 143-306). Elsevier. https:// doi.org/10.1016/B978-0-12-381468-5.00004-X.

Koussissi, E., Dourtoglou, V. G., Ageloussis, G., Paraskevopoulos, Y., Dourtoglou, T., Paterson, A., \& Chatzilazarou, A. (2009). Influence of toasting of oak chips on red wine maturation from sensory and gas chromatographic headspace analysis. Food Chemistry, 114(4), 1503-1509. https://doi.org/10.1016/j.foodchem.2008.11.003.

Lê, S., Josse, J., \& Husson, F. (2008). FactoMineR: An R Package for Multivariate Analysis. Journal of Statistical Software, 25(1), https://doi.org/10.18637/jss.v025. i01.

Liu, S., Wang, S., Yuan, G., Ouyang, X., Liu, Y., Zhu, B., \& Zhang, B. (2016). Effect of Oak Chips on Evolution of Phenolic Compounds and Color Attributes of Bog Bilberry Syrup Wine During Bottle-Aging. Jounal of Food Science, 81(11), 2697-2707. https:// doi.org/10.1111/1750-3841.13532.

Lona, A. A. (1996). Vinhos: Degustação. Elaboração e Serviço. Age.

Lucena, A. P. S., Nascimento, R. J. B., Maciel, J. A. C., Tavares, J. X., Barbosa-Filho, J. M., \& Oliveira, E. J. (2010). Antioxidant activity and phenolics content of selected Brazilian wines. Journal of Food Composition and Analysis, 23(1), 30-36. https://doi. $\operatorname{org} / 10.1016 /$ j.jfca.2009.08.004.

Macfie, H. J. H. (1989). Assessment of the sensory properties of food. Journal of Sensory Studies, 4, 129-148.

Marchal, A., Cretin, B. N., Sindt, L., Waffo-Téguo, P., \& Dubourdieu, D. (2015). Contribution of oak lignans to wine taste: Chemical identification, sensory char acterization and quantification. Tetrahedron, 71(20), 3148-3156. https://doi.org/10. 1016/j.tet.2014.07.090.

Marchal, A., Pons, A., Lavigne, V., \& Dubourdieu, D. (2013). Contribution of oak wood ageing to the sweet perception of dry wines. Australian Journal of Grape and Wine Research, 19(1), 11-19. https://doi.org/10.1111/ajgw.12013.

Meyners, M., \& Castura, J. C. (2014). Novel Techniques sensory. In G. Ares, \& P. Varela (Eds.). Novel Techniques in Sensory Characterization and Consumer Profiling (CRC Press, p. 408). Taylor \& Francis.

Meyners, M., Castura, J. C., \& Carr, B. T. (2013). Existing and new approaches for the analysis of CATA data. Food Quality and Preference, 30, 309-319. https://doi.org/10. 1016/j.foodqual.2013.06.010.

Minolta (1994). Precise color commmunication: Color control from feeding to instrumentantion.

Moskowitz, H. R. (1983). Product Testing and Sensory Evaluation of Foods. Food \& Nutrition Press, 605.

Mouret, M., Lo Monaco, G., Urdapilleta, I., \& Parr, W. V. (2013). Social representations of wine and culture: A comparison between France and New Zealand. Food Quality and Preference, 30(2), 102-107. https://doi.org/10.1016/j.foodqual.2013.04.014.

Niederle, P. A., \& Vitrolles, D. (2010). Indicações Geográficas e qualificação no setor vitivinícola brasileiro. Estudos Sociedade E Agricultura, 18(1), 5-55.

Noble, A. C., Arnold, R. A., Buechsenstein, J., Leach, E. J., Schmidt, J. O., \& Stern, P. M. (1987). Modification of a standardized system of wine aroma terminology. American Journal of Enology and Viticulture, 38, 143-146.

Padilha, C. V., Sh, d., Biasoto, A. C. T., Corrêa, L. C., Lima, M., Dos, S., \& Pereira, G. E. (2016). Phenolic compounds profile and antioxidant activity of commercial tropical red wines (Vitis vinifera L.) from Sao Francisco Valley, Brazil Carla. Journal of Food Biochemistry. https://doi.org/10.1111/jfbc.12346 (in press(October))

Parisien, L. (2016). Les Vins Du Nouveau Monde, Une Menace Pour Les Vins Français? Retrieved December 12, 2017, from http://lesgrappes.leparisien.fr/les-vins-dunouveau-monde-tendance/.

Parr, W. V., Mouret, M., Blackmore, S., Pelquest-Hunt, T., \& Urdapilleta, I. (2011). Representation of complexity in wine: Influence of expertise. Food Quality and Preference, 22(7), 647-660. https://doi.org/10.1016/j.foodqual.2011.04.005.

Pereira, G. E. (2013). Os vinhos tropicais em desenvolvimento no Nordeste do Brasil. Com Ciência, 149, 13-15.

Pizarro, C., Rodríguez-Tecedor, S., Esteban-Díez, I., Pérez-Del-Notario, N., \& GonzálezSáiz, J. M. (2014). Experimental design approach to evaluate the impact of oak chips and micro-oxygenation on the volatile profile of red wines. Food Chemistry, 148, 357-366. https://doi.org/10.1016/j.foodchem.2013.10.039.

Ribereau-Gayon, J., \& Peynaud, E. Y. O. (1980). Ciências e Técnicas del vino. (Editorial Hemisfério Sur).

Ribereau-Gayon, P., Glories, Y., Maujean, A., \& Dubourdieu, D. (2006). Phenolic compounds. Handbook of Enology: The Chemistry of Wine and Stabilization and Treatments. Vol. 2. Handbook of Enology: The Chemistry of Wine and Stabilization and Treatments (pp. 141-203)

Sánchez-Palomo, E., Trujillo, M., Ruiz, A. G., \& Viñas, M. A. G. (2017). Aroma pro fi le of malbec red wines from La Mancha region: Chemical and sensory characterization. Foodservice Research International. https://doi.org/10.1016/j. foodres.2017.06.036.

Schumacher, R., Alañón, M. E., Castro-Vázquez, L., Pérez-Coello, M. S., \& Díaz-Maroto, M. C. (2013). Evaluation Of Oak Chips Treatment On Volatile Composition And Sensory Characteristics Of Merlot Wine. Jounal of Food Quality, 36, 1-9.

Sherman, E., Greenwood, D. R., Villas-Boâs, S. G., Heymann, H., \& Harbertson, J. F. (2017). Impact of Grape Maturity and Ethanol Concentration on Sensory Properties of Washington State Merlot Wines. American Journal of Enology and Viticulture, 16076. https://doi.org/10.5344/ajev.2017.16076 (ajev.2017).

Stone, H., \& Sidel, J. L. (2004). Sensory evaluation practices (3 ed.). California: Elsevier.

Tao, Y., García, J. F., \& Sun, D. (2014). Advances in Wine Aging Technologies for Enhancing Wine Quality and Accelerating Wine Aging Process. Critical Reviews in Food Science and Nutrition, 54, 817-835. https://doi.org/10.1080/10408398.2011. 609949

Valentin, D., Chollet, S., Lelièvre, M., \& Abdi, H. (2012). Quick and dirty but still pretty 
good: a review of new descriptive methods in food science. International Journal of Food Science and Technology, 47(8), 1563-1578. https://doi.org/10.1111/j.13652621.2012.03022.x.

Vidal, L., Giménez, A., Medina, K., Boido, E., \& Ares, G. (2015). How do consumers describe wine astringency ? Food Research International, 78, 321-326. https://doi.org/ 10.1016/j.foodres.2015.09.025.

Vieira, A. C. P., Watanabe, M., \& Bruch, K. L. (2012). Perspectivas de Desenvolvimento da
Vitivinicultura Em Face Do Reconhecimento Da Indicação de Procedência Vales da Uva Goethe. Revista Gestão, Inovação E Tecnologia, 2(4), 327-343. https://doi.org/10. 7198/S2237-0722201200040001.

Villanueva, N. D. M., \& Da Silva, M. A. A. P. (2009). Comparative performance of the nine-point hedonic, hybrid and self-adjusting scales in the generation of internal preference maps. Food Quality and Preference, 20(1), 1-12. https://doi.org/10.1016/j. foodqual.2008.06.003. 